\title{
Nature-based tourism and nature protection: quality standards for travelling in pro- tected areas in the Alps
}

\author{
Dominik Siegrist \& Lea Ketterer Bonnelame
}

Keywords: Alps, sustainability, nature-based tourism, traditional cultural landscape, nature protection, quality standards, tourism destinations, case studies

\section{Abstract}

Nature-based tourism is an important element of ecological and sustainable development in the Alps. A functioning quality management programme is essential to ensure high-quality nature-based tourism. The authors developed ten quality standards, differentiated by five quality-related criteria with associated indicators. Standards were developed by involving experts from all Alpine countries and using an Alpine-wide online survey; the standards were tested in six case studies. The quality standards are available to various destinations in the form of a checklist.

\section{Introduction}

At the beginning of the $21^{\text {st }}$ century, nature-based tourism is enjoying a worldwide boom, and it is unclear when it might end (Kuenzi \& McNeely 2008). The reasons for this are manifold and depend, for instance, on the need for recreation in intact nature for more urbanized societies. The world's most important major destinations of nature-based tourism are located outside the European Alps in North America, Australia and New Zealand, Central Asia and the Himalayas, South America and Scandinavia (Fredman \& Tyrväinen 2010; Hall \& Boyd 2005; Lundmark \& Müller 2010). But the European Alps, too, offer a large number of natural and landscape spaces with a wide range of opportunities for nature-based tourism. Today we can identify an increasing demand for nature-based leisure options in the Alps and a trend towards nature-based tourism. Visitors are looking for authentic experiences in natural activities and spaces, independent of technical infrastructure (Bätzing 2002; Messerli 1999; Pröbstl-Haider et al. 2014).

Nature-based tourism, with its many facets and forms, constitutes an important element of ecological and sustainable development in the Alps. This type of tourism is primarily found in historically evolved, extensive cultural landscapes with high scenic and ecological qualities. Nature-based tourism involves offering guests a responsible stay in natural areas and it features cultural landscapes embedded in nature, which developed from regional needs and with the participation of numerous parties. In this way, environmental, social, cultural and economic conditions need to be respected, permanently protected, promoted and sustainably funded. Nature-based tourism makes the diversity of natural and cultural landscape values of a given region tangible for its visitors, actively engaging them and incorporating all their senses. This form of tourism can create jobs for locals while adding regional value (Siegrist et al. 2015).

Several different types of tourism which are more or less closely connected to nature-based tourism are listed in Figure 1. This image shows how different approaches to touristic options can be positioned between weak and strong sustainability (Baumgartner 2008; Baumgartner \& Röhrer 1998; Becker et al. 1996; Losang 2000) and between high and low nature orientation (Broggi 2015). The boundaries are fairly fluent and the figure has to be seen as a guideline. Both nature-based tourism and ecotourism have a strong on nature. In its current specifications, ecotourism is not necessarily strongly sustainable (for example, when travelling overseas) (Baumgartner 2008; Baumgartner \& Röhrer 1998); otherwise, sustainable tourism does not present a high nature orientation, as it may also include urban tourism, for example. Approaches such as rural tourism and agro tourism (Rein \& Schuler 2012) can be applied relatively widely, and they may show different characteristics on nature orientation and sustainability.

Environmental education is currently being offered, and has a highly sensitizing effect when combined with hiking. It can also be offered through classic and modern mountain and outdoor sports, such as mountain climbing, skiing, mountain biking and snowshoeing. Important action fields, such as mobility, energy and spatial planning, should also be considered. In this way nature-based tourism can be regarded as a nature-based form of sustainable tourism. One important, yet largely ignored, aspect of nature-based tourism is that nature-based tourism - together with other forms of tourism - should contribute to financing nature and landscape protection (Baumgartner 2008; Job et al. 2014; Ketterer Bonnelame \& Siegrist 2014; Rütter-Fischbacher et al. 2010).

Tourist destinations play an important role in promoting nature-based tourism. Destination Management Organizations (DMOs) encourage the development of tourism portfolios and communicate the tourism products to the market. With regard to naturebased tourism, the DMOs aim to create and market high-quality and marketable products to visitors. To achieve this goal, considerations about the quality of nature-based tourism are important. Appropriate qual- 
ity standards were developed as part of a project funded by the Bristol Foundation. Standards were developed with the involvement of experts from all Alpine countries and using an Alpine-wide online survey; it was also tested in six case studies (Siegrist et al. 2015).

\section{Methodological approach}

The development of quality standards in naturebased tourism in the Alps involved three project phases. In the first phase the basic principles of naturebased tourism were analysed by means of literature and document research. It also included 14 semi-structured interviews conducted with experts; subsequently a first draft of quality standards was developed. Based on the results of the first phase, an Alpine-wide online survey was produced in four languages. This survey pertained to nature-based tourism and was carried out in the Alpine region among tourism representatives and other relevant stakeholders. The results of this survey served to revise and specify the tourism-based quality standards. The survey yielded 1365 completed questionnaires, the majority of them answered in German, a smaller proportion in Italian and French, and the smallest share completed in Slovenian. The third phase of the project involved the discussion of draft quality standards with representatives of key stakeholder groups.

In parallel, quality standards were tested on the basis of five case studies: Naturel Régional Massif des Bauges (France)/Massif des Bauges Regional Nature Park (45.68745 N, 6.13549 E), Parco Nazionale Gran Paradiso (Italy) / Gran Paradiso National Park (45.51837 N, 7.26659 E), Naturparkregion LechtalReutte (Austria) / Lechtal-Reutte Nature Park Region (47.48561 N, $10.71501 \mathrm{E})$, holiday regions Engadin Scuol Val Müstair (Switzerland) (46.79687 N, 10.29774 E) and Solčavsko region (Slovenia) (46.40235 N, 14.68023 E), see also Figure 3. A sixth case study, which will not be discussed further at this point, involved an outdoor activities provider. The importance of nature-based tourism at the destination, destination type, the importance of large protected areas (LPAs) at the destination and the distribution of the case studies across the Alpine countries were decisive for selecting the case studies: a national park and a regional natural park / geopark in Italy and France; a region, a natural park region and a destination with two landscape parks (nature parks) in Switzerland, Austria and Slovenia. In two case studies nature-based tourism is the main business area, while in the three other cases nature-based tourism is a partial business area. The importance of LPAs varied greatly between the case studies. In three case studies the LPA is central, in the other two it was less significant.

The five case studies were used to determine whether the developed quality standards, criteria and indicators adequately took account of the initial and problem situation of the case studies in terms of na-

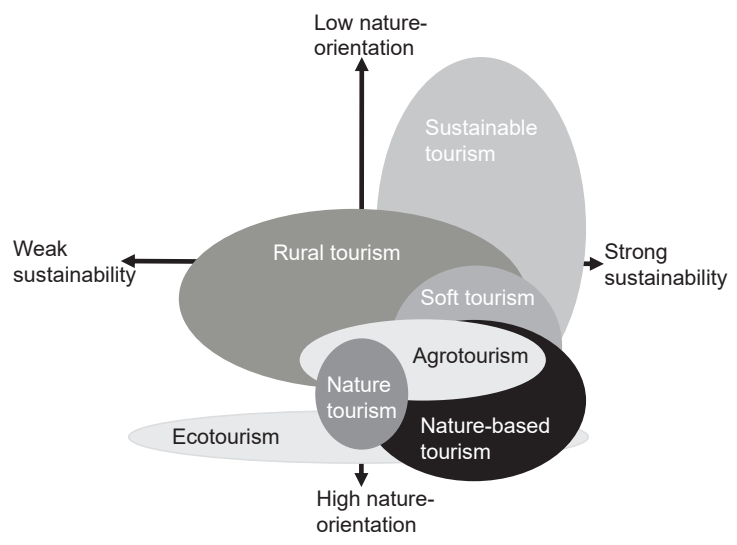

Figure 1 - Nature orientation and sustainability of different forms of tourism.

ture-based tourism. It was equally interesting to find out whether the present checklist as a whole was applicable and useful in practice and in what context it could be used sensibly. The test runs for the verification of the quality standards were iterative and carried out in cooperation with the representatives of the case studies on site. The original design of the quality standards and the checklist was refined on the basis of the findings from the case studies. In a first round the representatives of the five areas filled in the checklist as a self-evaluation and based on their own assessment. Then they sent the completed checklist back to the project team. There followed one or several telephone interviews with the representatives of the case studies to tease out details of individual points. At the same time the case study representatives also provided feedback on the quality standards as well as on the structure and content of the checklist. Based on these feedbacks and the results of an expert workshop, the checklist was adapted again.

\section{Results}

Quality standards for nature-based tourism in the Alps

Quality has long been an important competitive tool in tourism. Guests expect high-quality services and they opt for experiences with a good price-performance ratio. For many guests environmental protection and sustainability is an important and self-evident component of quality (Müller 2004).

Several existing standards in international tourism are geared towards the environment and sustainability. These guidelines extend beyond legal requirements when measuring environmental protection and sustainability. Such standards generally focus on environmental performance and corporate social responsibility, as well as on the environmental quality of products and services. Users of such standards may include different service providers, tour operators, accommodation providers, restaurants, sports and leisure facilities, attractions, transport companies, outdoor activity pro- 


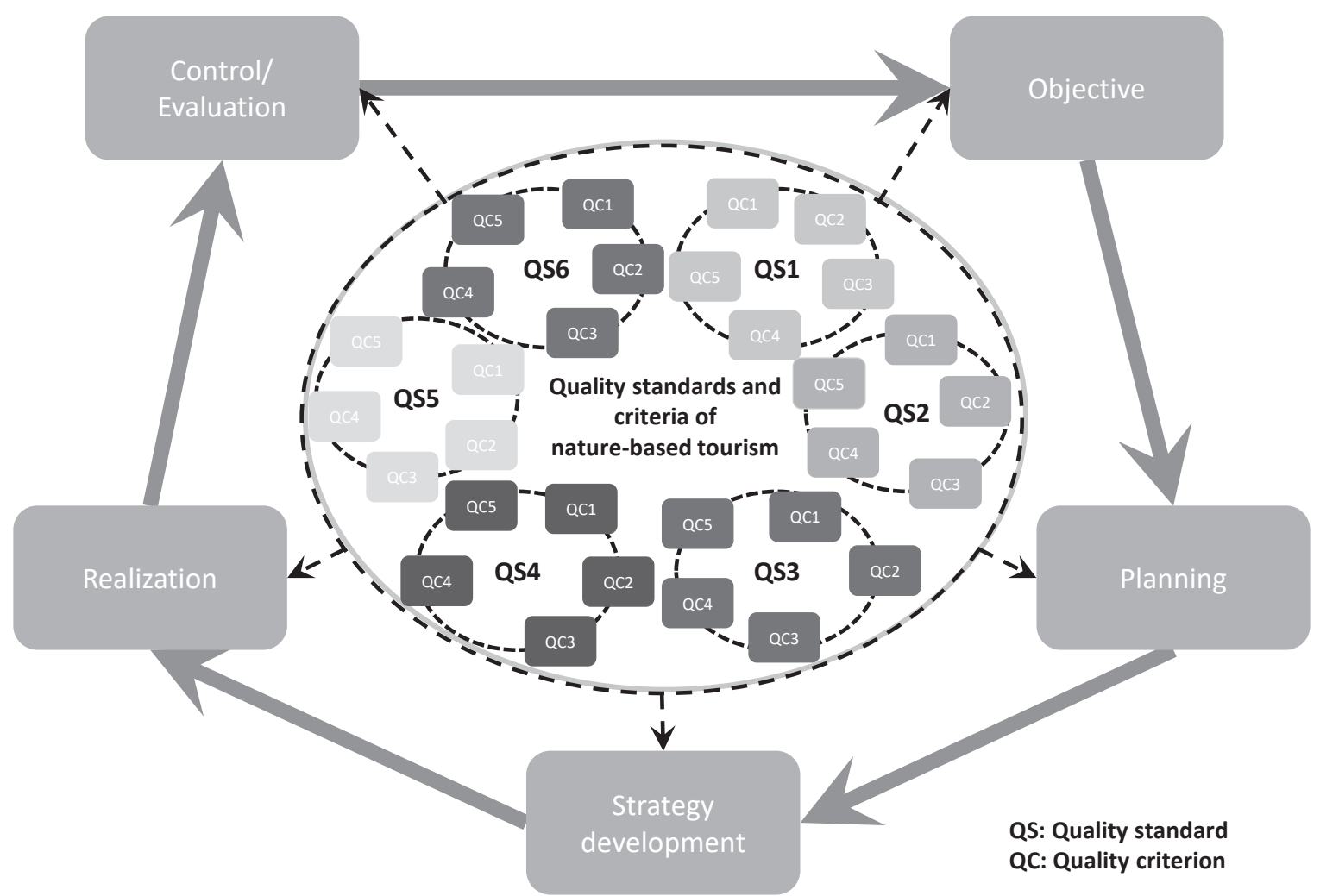

Figure 2 - Management cycle in nature-based tourism in the Alps.

viders, but also entire destinations, tourism organizations and ministries (Plüss \& Zotz 2012).

Although many standards for sustainable tourism exist, comparatively few of them are applied within the Alpine space. Obviously such standards are difficult to implement in today's practices of Alpine tourism, especially if they lead to applicable label. This fact, in addition to the lack of clarity in existing labels and standards, may mean that the establishment of a new label, or even a brand of nature-based tourism in the Alps, is not very feasible. Therefore no label was sought with these newly developed quality standards. Rather, these labels constitute a guideline for self-evaluation, which can be used to assess the state of a destination in terms of its nature-based tourism. These elements can also be employed to formulate options for action and improvement.

One challenge in this investigation was to identify those indicators that allow for measuring compliance with the specified criteria. In order to apply them in tourism practice, indicators are needed that can be collected by simple means. Therefore special attention was paid to this aspect in the development of the quality standards (Baumgartner 2008; Europäische Union 2013; Permanent Secretariat of the Alpine Convention 2013).

Development of quality standards for naturebased tourism in the Alps

When deriving quality standards for nature-based tourism in the Alps, the addressees of such standards must be identified. One must indicate precisely which groups of Alpine tourism actors are targeted in the development of quality standards. The study chose an actor-oriented approach, with destinations, as well as DMOs and service providers - which control and manage tourism in most destinations of the Alps - as the main target groups. Only through these actors can nature-based tourism succeed and play a more central role in Alpine tourism. However, actors of naturebased tourism are in a field of conflict between destinations, guests, local population and actors of Alpine protection.

Quality standards for nature-based tourism represent a normative basis for the management of a destination. They show how nature-based tourism can be designed and further developed and they can identify which needs should be met. Figure 2 illustrates how quality standards (QS) can be considered in all phases of the management cycle of tourism destinations. Each QS includes a set of quality criteria (QC).

\section{Results of the case studies}

More than a third of the individual criteria of the case studies are fulfilled and almost half of the individual criteria are partially met. Only a relatively small part of the criteria remains unfulfilled. This good result may be surprising at first, however, it is important to note that case studies selected were places where nature-based tourism is already seen as highly relevant.

Among the individual quality standards Nature-based marketing, Promotion of regional added value and Nature- 


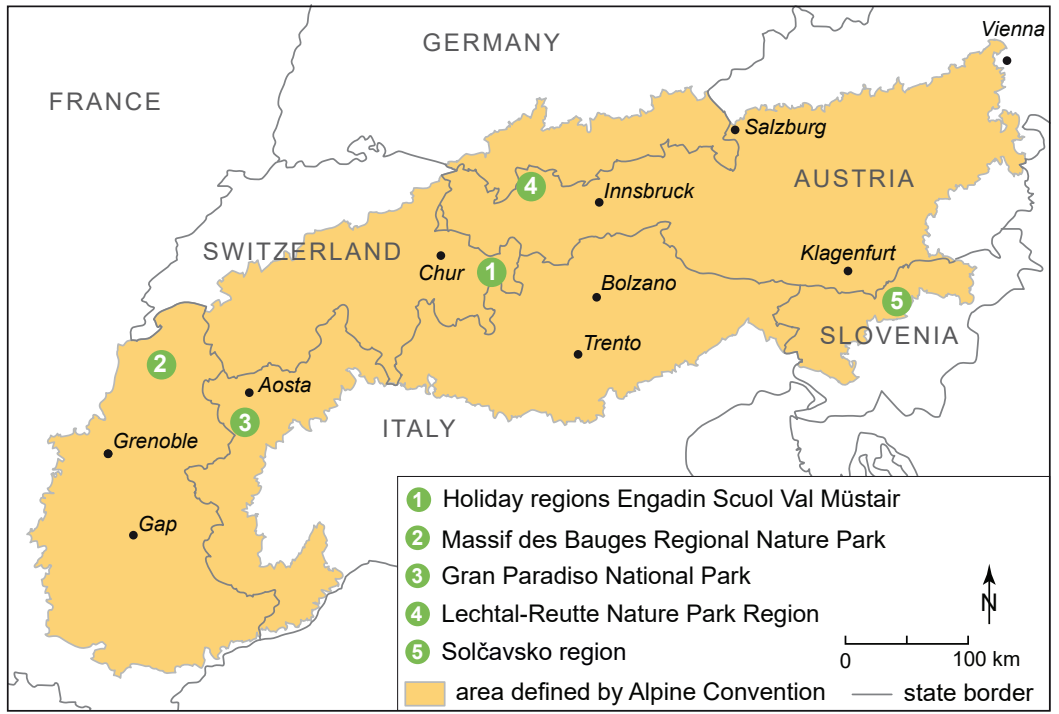

Figure 3 - Case studies in pilot regions in five countries of the Alps. Cartography: K. Heinrich / T. Felzmann

based development of offers were rated best. Nature-based region and Information \& sensitization also received a high rating. At the lower end of the ranking are the quality standards Nature protection and landscape development, Accommodation and catering and Quality management. The quality standards Fostering sustainable transport planning and Quality of the place in terms of architecture, landscape and space are found in midfield. In general, it is noticeable that quality standards more closely aligned to economic development were ranked higher, whereas quality standards linked to regulation and connected to nature and landscape were ranked lower.

Overall, however, the protection and enhancement of nature and landscape in the pilot regions is of great importance and all the surveyed destinations live up to it more or less successfully. They all include LPAs, mostly connected to a nature protected area. Land-use planning is perceived as an important instrument of conservation but only partially applied in an effective manner, and approaches for a qualitative development of settlement areas are largely absent. Conservation projects, as well as activities with volunteers and visitor management measures, are common in the areas covered by the project. The relatively loose cooperation between destinations and private conservation organizations means that valuable synergies are lost. On the other hand, tourism managers consider information and awareness of the visitors and the population relevant, and LPAs play an important role therein. In most pilot areas several events take place annually on topics of environmental and nature conservation and a broad excursion programme is offered. The visitor and information centres, which are available in all places, increasingly convey nature and landscape topics with the use of modern didactics and IT technology for interpretation.

\section{Discussion and conclusion}

Up until now there had been no holistic criteria system for nature-based tourism in the Alps. A set of quality standards and criteria has been developed on the basis of existing quality systems regarding environment and sustainability in tourism. The quality standards set out here are intended to serve as a guideline for tourism professionals for their practical work (Siegrist et al. 2015). The project team placed great emphasis on the application-orientation of the quality standards. Representatives from practice were involved in each development step. By checking the quality standards via the case studies, the criteria could be sharpened and adapted to the specific needs of the destinations. Like other management tools, the quality standards proposed here, and self-evaluation based on them, have their strengths and weaknesses. Strengths lie in the standardized approach, in the clearly formulated criteria with easily measurable indicators and in the possibility of using the quality standards as a communication tool. Weaknesses are found in the length of the checklist, the spatial and institutional system delimitation, the operationalization for differently structured destinations, and the generally difficult data situation. Another difficulty is that self-evaluations can never be completely independent and therefore have smaller or greater misjudgements. And, ultimately, the biggest challenge is that tourism stakeholders finally implement the quality standards.

However, the future of nature-based tourism in the Alps does not depend solely on how professionally and consistently it is implemented at the destinations. Just as the adoption of a nature-based tourism perspective is essential, so are the future development of a nature-based tourism framework, in addition to general social developments. The biggest challenge faced in the development of nature-based tourism in the Alps lies in raising the sensitivity of service providers and the local population to the protection and sus- 
tainable development of the Alps. However, visitors should also be better informed about the situation in the Alps by being provided with information and environmental education, which require the professional education and training of those working in tourism. This concerns in particular tourist destinations and their service providers and key enterprises. Naturebased tourism can only be successful if it is integrated at a central point in the overall development strategy. A clear legal framework (e.g. land-use planning, conservation and environmental protection) serves as an important basis for this strategy.

The question of the future prospects of naturebased tourism in the Alps cannot be viewed separately from its overall social development (Siegrist et al. 2015). The coming decades in the Alpine countries will be accompanied by major changes. Touristic source markets will shift as a result of demographic changes and the effects of migration. Changing habits will lead to new options and activities that are not foreseeable today but will, at least partly, continue to take place in nature. Safety issues arising from new natural hazards are becoming an increasingly important issue. At a certain point the rising energy prices will lead to changes in travel behaviour, which may attract more visitors from the areas surrounding the Alpine destinations. The consequences of climate change will be even more visible than they are today. Many ski resorts will face even more pressure from the lack of snow, but the Alpine summers will be milder and more attractive. However, the global climate and resource crisis will also come to a head, resulting in high costs that may strain our wealth and thus our travel budget.

Despite all these partially difficult and foreseeable developments associated with the environment, society and the economy, it is likely - given the further urbanization and mechanization of our world - that the need for nature and authenticity on vacation is increasing. However, an open question remains: Does this need include the desire for sustainability, environmental and climate protection in the future? Currently, sustainable actions and new holiday habits are not (yet) noticeable on a large scale. Against this background, the promotion of nature-based tourism should start at three levels - at the level of policy, the population and the individual destinations:

- At policy level, there is a need for an appropriate framework so that nature-based tourism and sustainable action can be effective in the first place. For a sustainable and nature-based tourism policy to be developed, it is of great importance that tourism stakeholders positively support, and not fight against, the ongoing political efforts that are made towards environmental sustainability.

- At the general public and visitor level, costs are the main argument. As long as non-environmentally friendly deals are cheaper than environmentally sound ones, demand will not move significantly towards nature-based tourism and sustainability.
- At the level of destinations, tourism service providers represent crucial key areas of action; these individuals should handle their own natural and scenic resources carefully, while also consistently promoting nature-based tourism.

Today there are many good examples of naturebased tourism and sustainable development in the Alps and around the world. However, these examples suffer from unsuitable conditions and are thus not able to develop in the necessary breadth. In today's highly networked economy, and within the context of our current society, tourism alone is not able to cope with challenges like climate change or biodiversity loss. As such, overarching policies and strategies are needed at national and international level, and organizations need to be provided with the necessary financial means to establish these policies. The tourism industry itself holds a great deal of responsibility to solve its own problems, particularly as this industry is the major contributor to these problems. This is reason enough for us to take advantage of the existing potential in the Alps and to prioritize nature-based tourism in as many destinations as possible.

\section{References}

Bätzing, W. 2002. Der Stellenwert des Tourismus in den Alpen und seine Bedeutung für eine nach-haltige Entwicklung des Alpenraumes. In: K. Luger \& F. Rest (eds.), Der Alpentourismus. Entwicklungspotenziale im Spannungsfeld von Kultur, Ökonomie und Ökologie. Tourismus: transkulturell \& transdisziplinär, Band 5: 175-196. [In German]

Baumgartner, C. 2008. Nachhaltigkeit im Tourismus. Von 10 Jahren Umsetzungsversuchen zu einem Bewertungssystem. Innsbruck. [In German]

Baumgartner, C. \& C. Röhrer 1998. Nachhaltigkeit im Tourismus. Umsetzungsperspektiven auf regionaler Ebene. Wien, Köln. [In German]

Becker, C., H. Job \& A. Witzel 1996. Tourismus und nachhaltige Entwicklung. Grundlagen und praktische Ansätze für den mitteleuropäischen Raum. Darmstadt. [In German]

Broggi, M. 2015. Wieviel Wildnis für die Schweiz. Ein Diskussionsbeitrag (Essay). Schweizerische Zeitschrift für Forstwesen 166(2): 60-66. [In German]

Europäische Union 2013. Europäisches Tourismusindikatorensystem. TOOLKIT für nachbaltige Destinationen. Luxemburg. [In German]

Fredman, P. \& L.Tyrväinen 2010. Frontiers in Nature Based Tourism. Scandinavian Journal of Hospitality 10(3): 177-189.

Hall, M. \& S. Boyd (eds.) 2005. Nature-based tourism in peripheral areas. Development or disaster? Clevedon, Buffalo.

Job, H., M, Mayer \& F. Kraus 2014. Die beste Idee, die Bayern je hatte: der Alpenplan. Gaia 23(4): 335345. [In German] 
Ketterer Bonnelame, L. \& D. Siegrist 2014. Biodiversität und Tourismus. Instrumente im Tourismus zur Förderung der Biodiversität. Schriftenreihe des Instituts für Landschaft und Freiraum. HSR Hochschule für Technik Rapperswil 11. Rapperswil. [In German]

Kuenzi, C. \& J. McNeely 2008. Nature-based tourism. In: Renn, O. \& K. Walker (eds.), Global risk governance. Concept and practice using the IRGC framework: 155-178.

Losang, E. 2000. Tourismus und Nachbaltigkeit. Trierer Tourismus-Bibliographien, Band 12. Trier. [In German]

Lundmark, L. \& D. Müller 2010. The supply of nature-based tourism activities in Sweden. Tourism review 58(4): 379-393.

Messerli, P. 1999. Mensch und Natur im alpinen Lebensraum. Risiken, Chancen, Perspektiven. Bern/Stuttgart.

Müller, H.R. 2004. Qualitätsorientiertes TourismusManagement: Wege zu einer kontinuierlichen Weiterentwicklung. Bern.

Permanent Secretariat of the Alpine Convention 2013. Sustainable Tourism in the Alps. Report on the State of the Alps. Alpine Signals - Special Edition 4. Innsbruck.

Plüss, C. \& A. Zotz 2012. Nachhaltigkeit im Tourismus. Wegweiser durch den Labeldschungel. Available at: http://www.tourism-watch.de/files/nfi_ tourismus_labelguide_zweite_auflage_de_web_0.pdf (accessed: 22/03/15)

Pröbstl-Haider, U., V. Wirth \& W. Haider 2014. Wie viel „Natur“ suchen deutsche Urlauberinnen und Urlauber in den Alpen? Eine Quellgebietsstudie bezogen auf den Sommertourismus. Natur und Landschaft 89(1): 32-36.

Rein, H. \& A. Schuler 2012. Tourismus im ländlichen Raum. Wiesbaden.

Rütter-Fischbacher, U., C. Schmid \& H. Müller 2010. Vorstudie Indikator naturnaher Tourismus. Im Auftrag des Bundesamtes für Umwelt (BAFU). Bern/Rüchlikon. Available at: http://www.ruetter-
soceco.ch/cm/jdownloads//Zusammenfassung $+\mathrm{V}$ orstudie+Indikator+naturnaher+Tourismus.453.pdf (accessed: 11/09/2016)

Siegrist, D., S. Gessner \& L. Ketterer Bonnelame 2015. Naturnaher Tourismus. Qualitätsstandards für sanftes Reisen in den Alpen. Bern.

\section{Authors}

\section{Dominik Siegrist ${ }^{1}$}

studied geography at the University of Zurich and at FU Berlin. He has a Doctorate in Geography and a Habilitation in Landscape Planning. Guest research stays took him to the University of Natural Resources and Life Sciences in Vienna (Austria) and the Simon Fraser University in Vancouver (Canada). He used to run a private consulting office. Today he heads the Institute for Landscape and Open Space at HSR (Hochschule für Technik Rapperswil) and the section Nature-based Tourism and Parks. His research focuses on nature-based/sustainable tourism, parks/ large protected areas, nature sports and visitor management. Institute for Landscape and Open Space. Email: dominik.siegrist@hsr.ch

\section{Lea Ketterer Bonnelame ${ }^{1}$}

studied economics and human geography at the University of Zurich and at Lund University (Sweden), obtaining a Master's degree in 2007. Research stays took her to the Seychelles Islands Foundation, working in the UNESCO World Natural Heritage Vallée de Mai in the Seychelles. Today she is a researcher at the Institute for Landscape and Open Space at HSR Hochschule für Technik Rapperswil. Her research focuses on nature-based tourism, protected areas and parks, and biodiversity and tourism. E-mail: lea. ketterer@hsr.ch

${ }^{1}$ HSR Hochschule für Technik Rapperswil, Oberseestr. 10, CH-8640 Rapperswil. www.ilf.hsr.ch 